\title{
CPE Gene Product
}

National Cancer Institute

\section{Source}

National Cancer Institute. CPE Gene Product. NCI Thesaurus. Code C106412.

A protein encoded by the CPE gene. 